\title{
PHYLOGENY OF ACRIDOCARPUS-BRACHYLOPHON (MALPIGHIACEAE): IMPLICATIONS FOR TERTIARY TROPICAL FLORAS AND AFROASIAN BIOGEOGRAPHY
}

\author{
Charles C. Davis, ${ }^{1}$ Charles D. Bell,${ }^{2}$ Peter W. Fritsch, ${ }^{3}$ and Sarah Mathews 4 \\ ${ }^{1}$ Department of Ecology and Evolutionary Biology, University of Michigan Herbarium, 3600 Varsity Drive, \\ Ann Arbor, Michigan 48108-2287 \\ E-mail: chdavis@umich.edu \\ ${ }^{2}$ Department of Ecology and Evolutionary Biology, Yale University, P.O. Box 208106, New Haven, Connecticut 06520 \\ E-mail: charles.bell@yale.edu \\ ${ }^{3}$ Department of Botany, California Academy of Sciences, Golden Gate Park, San Francisco, California 94118 \\ E-mail:pfritsch@calacademy.org \\ ${ }^{4}$ Division of Biological Sciences, University of Missouri, Columbia, Missouri 65211 \\ E-mail: mathewss@missouri.edu
}

\begin{abstract}
A major tenet of African Tertiary biogeography posits that lowland rainforest dominated much of Africa in the late Cretaceous and was replaced by xeric vegetation as a response to continental uplift and consequent widespread aridification beginning in the late Paleogene. The aridification of Africa is thought to have been a major factor in the extinction of many African humid-tropical lineages, and in the present-day disparity of species diversity between Africa and other tropical regions. This primarily geologically based model can be tested with independent phylogenetic evidence from widespread African plant groups containing both humid- and xeric-adapted species. We estimated the phylogeny and lineage divergence times within one such angiosperm group, the acridocarpoid clade (Malpighiaceae), with combined ITS, $n d h F$, and $\operatorname{trnL}-F$ data from 15 species that encompass the range of morphological and geographic variation within the group. Dispersal-vicariance analysis and divergence-time estimates suggest that the basal acridocarpoid divergence occurred between African and Southeast Asian lineages approximately 50 million years ago (mya), perhaps after a southward ancestral retreat from high-latitude tropical forests in response to intermittent Eocene cooling. Dispersion of Acridocarpus from Africa to Madagascar is inferred between approximately 50 and 35 mya, when lowland humid tropical forest was nearly continuous between these landmasses. A single dispersal event within Acridocarpus is inferred from western Africa to eastern Africa between approximately 23 and 17 mya, coincident with the widespread replacement of humid forests by savannas in eastern Africa. Although the spread of xeric environments resulted in the extinction of many African plant groups, our data suggest that for others it provided an opportunity for further diversification.
\end{abstract}

Key words._Africa, aridification, Asia, biogeography, dispersal-vicariance analysis, East African Rift Valley, Madagascar, nonparametric rate smoothing, phylogeny.

Received May 21, 2002. Accepted September 4, 2002.

Lowland tropical rainforest dominated much of the African continent from the late Cretaceous through the Eocene-Oligocene (Raven and Axelrod 1974; Axelrod and Raven 1978). During its maximum extent in the late Paleogene, this species-rich assemblage covered most of northern Africa, including areas now occupied by the Sahara Desert, and extended southward to approximately $9^{\circ}$ south latitude, spanning the entire continent from east to west (Axelrod and Raven 1978). Its contraction has been attributed primarily to the uplift of the continent and the formation of the East African Rift Valley (King 1962; Axelrod 1972a; Baker et al. 1972; Raven and Axelrod 1974), resulting in broad scale aridification (Axelrod 1972a; Raven and Axelrod 1974; Axelrod and Raven 1978). In addition, other secondary factors that contributed to increasing aridity in Africa included the opening of the Southern Ocean (Bartek et al. 1992) and the closure of the Tethys Seaway to the north (Potts and Behrensmeyer 1992). Madagascar, which once shared this lowland forest with Africa (Raven and Axelrod 1974; Axelrod and Raven 1978), was apparently protected from the dramatic climate changes that influenced Africa beginning in the late Paleogene. It harbors many representatives of the rainforest flora that are now extinct on the continent (see Axelrod 1972a and references cited within; Raven and Axelrod 1974).
Neogene aridification in Africa is thought to have played a key role in the extinction of many tropical lineages from areas that once harbored rainforest taxa and in the resultant pattern whereby the modern continental flora of Africa is, on average, much less diverse than that of its Asian and South American counterparts (Axelrod 1972a; Raven and Axelrod 1974; Axelrod and Raven 1978; Whitmore 1998, p. 174). Stebbins (1952) and others (Axelrod 1972a; Whitmore 1998, pp. 105, 177) have suggested that the tremendous floristic diversity of lowland tropical western Africa, and of other similarly humid regions, results largely from the climatological stability experienced by these communities over time. Thus, new species would be expected to have accumulated gradually while ancient lineages remained intact. Stebbins (1952) also argued, however, that today's relatively speciespoor xeric regions may have supported as many as, or even more species than humid forests over equivalent periods of time, owing to rapid speciation and turnover in these communities. Axelrod (1972b) went further and suggested that this phenomenon applies not only to dry regions, but also to areas within mesic communities that are functionally xeric due to their nutrient-poor soils. If some originally humid lowland plant lineages were able to survive the onset of climatological change, they would today most likely inhabit the 


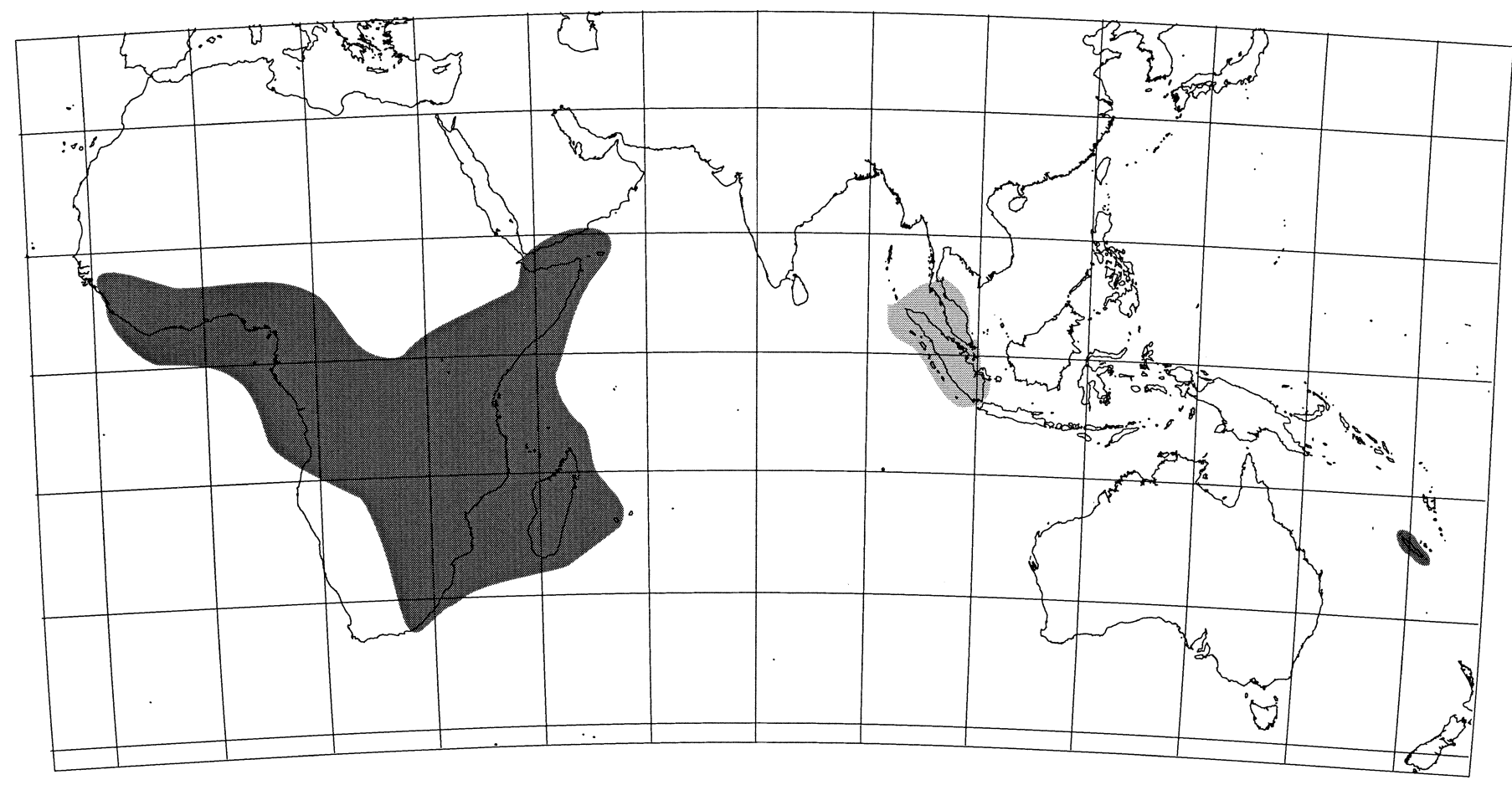

FIG. 1. Geographic distribution of acridocarpoid species estimated from Arènes (1957) and C. C. Davis (unpubl. data). There are approximately 30 species of Acridocarpus (shown in dark gray), which are widespread across western Africa (about 12 species), eastern Africa (about 11 species), Madagascar (about six species), and New Caledonia (one species). Brachylophon (shown in light gray) is monospecific and is widespread across the Malay Peninsula and Sumatra.

lowland rainforests of western Africa (Axelrod 1972a). And, if some of these lineages were able to further adapt to xeric climates, this new environment might have spurred their further diversification (Axelrod 1972a).

If this general biogeographic model of aridification over the African Tertiary is accurate, the responses of ancient African lowland rainforest plant communities to climate change should be detectable through phylogenetic analyses of plant lineages that span both humid lowland and xeric regions of the continent. If aridification induced a relatively recent period of diversification, then species that inhabit the relict forest of West Africa should represent the earliestdiverging lineages of these African radiations, whereas species restricted to arid regions of eastern Africa should be phylogenetically nested. Moreover, if Neogene aridification directly affected the diversification of these groups and caused a new phase in their evolution, the divergence between humid-adapted and dry-adapted lineages should coincide with the posited onset of Neogene aridification and concomitant vegetational change in Africa.

The acridocarpoid clade (Angiospermae: Malpighiaceae; sensu Davis et al. 2001) can be used to test these hypotheses. This clade contains two genera, Acridocarpus Guill. and Perr. and Brachylophon Oliv., which diverged from their closest New World ancestors during the lower Eocene (i.e., about 55 million years ago; Davis et al. 2002a). The approximately 30 species of Acridocarpus are distributed widely across Africa and Madagascar, with one species in New Caledonia (Niedenzu 1928; C. C. Davis, unpubl. data; Fig. 1). They exist in a variety of habitats ranging from lowland rainforest to savannas. Brachylophon is monospecific and grows in lowland rainforests of the Malay Peninsula and Sumatra (Fig. 1).

We sampled Brachylophon and morphologically diverse species of Acridocarpus from throughout their geographic ranges to estimate a phylogeny and test hypotheses of diversification relating to African biogeography. We inferred the phylogeny based on combined evidence from plastid $n d h F$ and $\operatorname{trn} L-F$ sequences, and from nuclear ribosomal internal transcribed spacer (ITS) sequences. The divergence time of the disjunction between Acridocarpus and Brachylophon was estimated by sampling nuclear phytochrome $\mathrm{C}$ (PHYC) from Brachylophon and adding it to the dataset of Davis et al. (2002a). This estimate was used to calibrate the ancestral node within the three-gene acridocarpoid tree, and to obtain approximate estimates of branching times that are independent of the available paleoclimatic data.

\section{Materials And Methods}

\section{Taxon Sampling}

To estimate the timing of the split between Acridocarpus and Brachylophon, we assembled a modified version of the global family level dataset analyzed by Davis et al. (2002a) based on nuclear PHYC and chloroplast $n d h F$ sequences. This dataset includes a newly generated $P H Y C$ sequence (GenBank accession number AY137337) and a previously generated (Davis et al. 2001) $n d h F$ sequence for Brachylophon curtisii. Both genes have been sampled from one outgroup, Androstachys johnsonii Prain (Euphorbiaceae), and from 71 species 
of Malpighiaceae representing the majority of genera within the family, including multiple accessions from morphologically diverse or putatively non-monophyletic genera. The dataset is available from the first author and TreeBASE (http: //www.treebase.org).

To investigate relationships within the acridocarpoid clade, we sampled ITS, $n d h F$, and $t r n L-F$ sequences from species that encompass the range of morphological diversity and geographic distribution within the clade (Niedenzu 1928; C. C. Davis, unpubl. data; Table 1). We sampled Brachylophon curtisii, as well as seven species of Acridocarpus from western Africa (of about 12 species), four from eastern Africa (of about 11 species), two from Madagascar (of about six species), and one from New Caledonia (of one species). In addition, sometimes multiple representatives from the same species were sampled. We sequenced ITS from 24 individuals (Table 1). We sequenced $n d h F$ and $t r n L-F$ from 20 of these, and the remaining four were generated previously (Davis et al. 2001; Table 1).

Barnebya Anderson and Gates, a New World genus of two species, was used as the outgroup to the acridocarpoids. Previous studies (Davis et al. 2001; Davis et al. 2002a) suggest that Barnebya is sister to a large clade of Malpighiaceae containing the majority of genera with wing-fruited vines that constitute the bulk of morphological diversity in Malpighiaceae. Anderson and Gates (1981) argued, however, that Acridocarpus and Barnebya are sister taxa based on two putative synapomorphies, alternate leaves (in a family that is almost wholly decussate-leaved) and nearly identical samaras. These two genera are also sister taxa in at least some matK trees of Malpighiaceae (Cameron et al. 2001).

\section{DNA Amplification, Cloning, and Sequencing}

Total genomic DNA was extracted with the DNeasy Plant Mini Kit protocol (QIAGEN, Valencia, CA). Tissue was obtained from specimens collected in the field and preserved in silica gel or from previously collected herbarium material. Polymerase chain reaction (PCR) conditions and visualization of PCR products mostly followed Davis et al. (2002b). The single exception was the newly generated PHYC sequence for Brachylophon curtisii, which was obtained by using the amplification, cloning, and sequencing protocols outlined in Mathews and Donoghue (1999) and Davis (2002). Polymerase chain reaction for $\operatorname{trn} L-F$ followed the protocol for $n d h F$ (Davis et al. 2002b). We used the same PCR amplification and sequencing primers as those used in Davis et al. (2002b) for ITS and $n d h F$ and in Davis et al. (2001) for trnL-F. Primer pair 972F and 2110R (Olmstead and Sweere 1994) was also used in some cases to obtain PCR fragments for $n d h F$. In most cases, the gel-purified ITS PCR products were cloned by following the protocols cited above for PHYC. We sequenced up to five clones from several species to assess polymorphism frequency (e.g., Wendel et al. 1995; Campbell et al. 1997). Double-stranded PCR products were sequenced in both directions with dye-terminators and cycle sequencing protocols (BigDye kit; Applied Biosystems, Foster City, CA). Sequences were edited with the computer program Sequencher 3.0 (Gene Codes Corporation, Ann Arbor, MI) and submitted to GenBank (Table 1).

\section{Phylogenetic Analyses}

The three single-gene datasets for the acridocarpoids were analyzed separately by using parsimony as implemented in PAUP* version 4.0b10 (Swofford 2000), with the branchand-bound option selected. Gapped positions were treated as missing data, characters were weighted equally, and character states were unordered. Bootstrap support (Felsenstein 1985) for each clade was estimated from 1000 heuristic search replicates with simple taxon addition (reference taxon was $A c$ ridocarpus adenophorus), tree-bisection-reconnection (TBR) branch-swapping, and MULPARS in effect. To assess the level of congruence between the chloroplast $(n d h F+t r n L$ $F$ ) and nuclear (ITS) data partitions, we employed the incongruence length difference test (ILD) (Farris et al. 1994), implemented in PAUP as the partition-homogeneity test. We used simple taxon addition (saving 10 trees per replicate) with all uninformative characters excluded, TBR branchswapping, and heuristic searches with 999 repartitions of the data. The ILD test was similarly implemented on the $n d h F$ and $P H Y C$ data partitions for the global dataset.

Maximum-likelihood analyses of the combined $n d h F$ and PHYC global dataset and of the combined ITS, $n d h F$, and $\operatorname{trn} L-F$ acridocarpoid data were conducted by using PAUP* version 4.0b10 for UNIX (Swofford 2000) with 300 random sequence addition replicates and TBR branch-swapping. We performed 300 bootstrap replicates to assess clade support. We used likelihood-ratio tests to choose a model of sequence evolution (Felsenstein 1981). A general time-reversible (GTR) model that included parameters for invariant sites and rate variation $($ GTR $+\mathrm{I}+\Gamma)$ best fit the data and was used to evaluate molecular rate constancy.

\section{Biogeography and Age Estimates}

Ancestral areas were reconstructed on the acridocarpoid tree with dispersal-vicariance analysis (DIVA version 1.1; Ronquist 1996, 1997). DIVA reconstructs ancestral areas by minimizing the number of dispersal and extinction events needed to explain a given distribution pattern. Vicariance is the default mode of speciation in DIVA, and such events are not counted as steps in identifying optimal solutions; each inferred dispersal event is counted as one step. The data matrix used to assess ancestral areas was constructed by scoring terminals according to their extant distribution. DIVA generally reconstructs widespread ancestors at the deepest nodes within a specified tree (Ronquist 1996, 1997). Because there are no modern acridocarpoid species distributed in multiple areas of endemism, we constrained our search to a maximum of two inferred ancestral areas by following the suggestion of Ronquist $(1996,1997)$ and Donoghue et al. (2001). DIVA reconstructions in this analysis were confined to ancestral areas within the acridocarpoid clade. The New World origin of the acridocarpoid stem lineage was previously inferred from Davis et al. (2002a).

Species distributions were determined from approximately 1000 herbarium collections of the acridocarpoids on loan to the first author for a taxonomic revision of Acridocarpus (C. C. Davis, unpubl. data). The distribution of the acridocarpoids translates to five major areas of endemism (Table 1): West Africa (including lowland and transitional forest dis- 


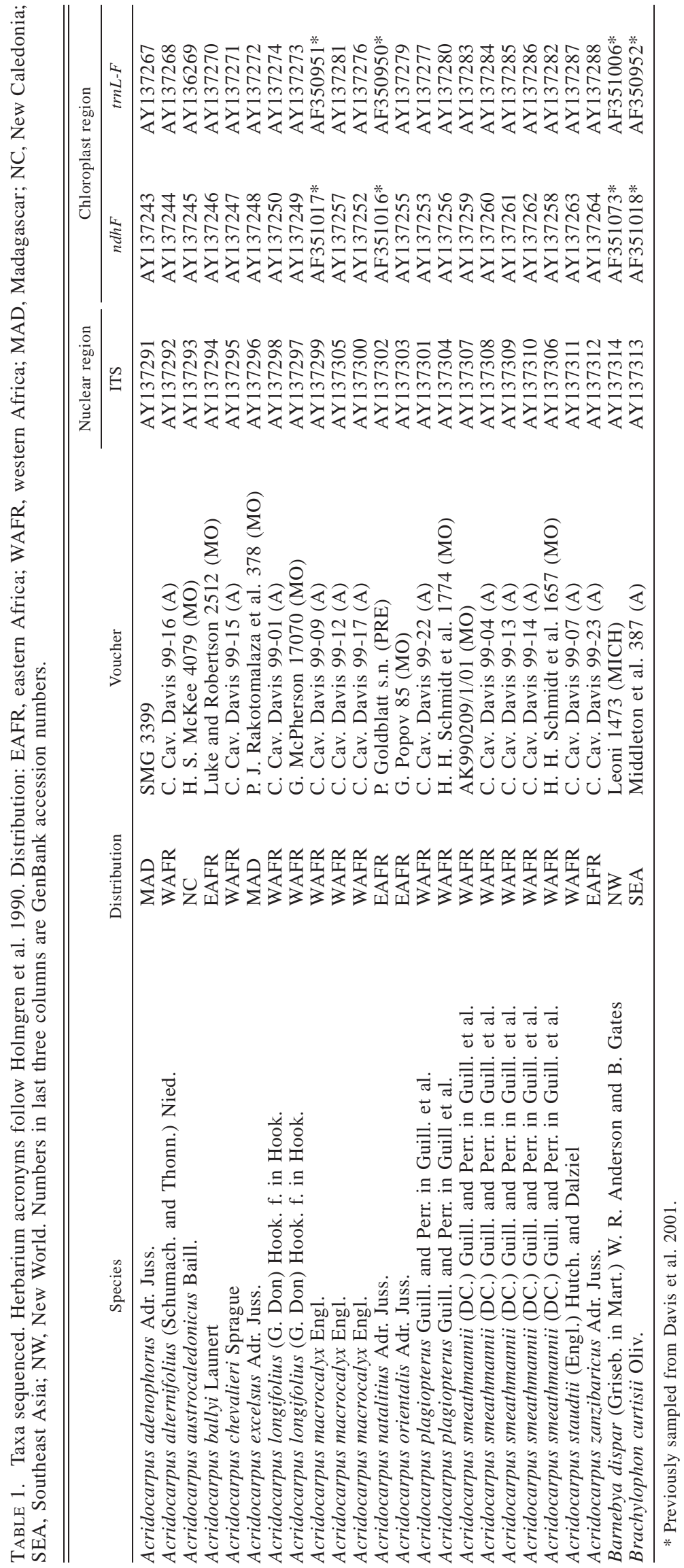


tributed across much of western and central Africa), East Africa (including East Africa proper as well as coastal regions of South Africa and Arabia), Madagascar, New Caledonia, and Southeast Asia. The East African Rift System is part of the longest rift in the world (i.e., Afro-Arabian rift system), and stretches from northeastern Sudan to the southern coast of Mozambique (Baker et al. 1972; Grove 1978). This forms a major vegetational break within the African continent (White 1983) and represents a primary split in the distribution of Acridocarpus species. Our designated areas of endemism in Africa approximately correspond to areas west (western Africa) and east (eastern Africa) of the Rift Valley.

Branch lengths and an associated likelihood score were calculated for the respective model of sequence evolution (i.e., GTR $+\mathrm{I}+\Gamma$ ) in the absence of a molecular clock. We used the tree resulting from maximum-likelihood searches to test for rate constancy among lineages under the assumption of a molecular clock using $2\left(-\ln \mathrm{L}_{1}-\ln \mathrm{L}_{0}\right)$ as a test statistic. This was compared to a $X^{2}$ distribution (with $n-2$ degrees of freedom, where $n=$ number of taxa) to assess significance. Because the assumptions of a clock were rejected $(P<0.05)$, we estimated divergence times using a nonparametric rate smoothing algorithm (Sanderson 1997) as implemented in the program r8s version 1.06 (available at http://ginger.ucdavis.edu/r8s/). To calculate the stochastic error of divergence time estimates associated with sampling a finite number of nucleotide characters, we used a parametric bootstrapping strategy similar to the nonparametric procedure of Baldwin and Sanderson (1998), as follows: (1) 100 datasets were simulated on the maximum-likelihood tree with the computer software Seq-Gen version 1.2.3 (Rambaut and Grassly 1997), (2) the resulting datasets were imported into PAUP and divergence times were estimated on the original topology with the sequence model and parameters estimated from the original data, and (3) the resulting branch-length estimates from the simulated datasets were used to calculate the variance in divergence-time estimates.

A fossil species of Tetrapterys from the early Oligocene (33 mya; Hably and Manchester 2000) of Hungary and Slovenia provides a reliable minimum age estimate for the $T e$ trapterys clade, and was used to calibrate the global tree inferred from $n d h F+P H Y C$ (see also Davis et al. 2002a). Although slightly older Eocene fossils of Malpighiaceae are known from other localities (e.g., Germeraad et al. 1968; Taylor and Crepet 1987), they are not readily assigned to any extant genus at this time, and are difficult to include as calibration points. The estimated age of the split between $A c$ ridocarpus and Brachylophon from this global analysis was subsequently used to calibrate divergence-time estimates for the three-gene acridocarpoid phylogeny.

\section{RESULTS}

\section{Sequences/Matrices}

The aligned $n d h F$ and $P H Y C$ sequences are 813 and 1180 base pairs (bp) long, respectively. The $n d h F$ and $P H Y C$ datasets are not significantly incongruent as determined from the ILD test $(P=0.52)$. The combined $n d h F+P H Y C$ data matrix for 72 taxa contains 928 variable and 564 parsimonyinformative characters.
The aligned $n d h F, t r n L-F$, and ITS acridocarpoid datasets are 730, 976, and 768 bp long, respectively. Most length variation occurs among trnL-F sequences due to several hypervariable A-T rich regions (see also Davis et al. 2001). There was no evidence that ITS was polymorphic within species of the acridocarpoids (GenBank accession numbers AY137315-AY137336). The chloroplast and nuclear datasets are significantly incongruent as determined by the ILD test $(P=0.01)$. This apparently results from the alternate position of the clade comprising Acridocarpus macrocalyx, A. plagiopterus, and A. staudtii between the two dataset partitions. In the ITS trees, this clade is sister to the other African species of Acridocarpus, as in Figure 2. In the chloroplast trees, however, this clade was placed with weak support (bootstrap value $=68 \%$ ) as sister to the Malagasy + New Caledonian clade. The two datasets are not significantly incongruent (ILD $P=0.30$ ) when the species of this clade are excluded. In addition, we used the Templeton test (Templeton 1983; see also Larson 1994) in PAUP to assess the significance of this conflict. We compared the most parsimonious trees generated from the chloroplast data with trees in which the African taxa formed a clade. Results from this test suggest that the topologies are not significantly different $(P>0.32)$. However, when the African taxa are constrained to be nonmonophyletic and compared with the most parsimonious trees generated from ITS, the topologies are significantly different $(P<$ $0.005)$. Based on these results, we combined the datasets for analysis. The combined 2474-bp-long data matrix contains 471 variable sites and 270 parsimony-informative sites for 15 ingroup taxa (23 accessions) and one outgroup.

\section{Phylogenetic Analyses}

The tree with the highest likelihood estimated from the $n d h F$ and $P H Y C$ family dataset is consistent with previous results (Davis et al. 2002a; tree not shown). In this tree, Brachylophon is sister (bootstrap value $=80 \%$ ) to Acridocarpus $(99 \%)$. Results from maximum-likelihood searches (Fig. 2) on the three-gene dataset also recover Brachylophon as sister $(80 \%)$ to Acridocarpus, and were identical to trees generated from parsimony (not shown).

The first split within Acridocarpus occurs between species from Africa and Madagascar + New Caledonia (Fig. 2; node C; 100\%). Within the Malagasy + New Caledonian clade (100\%), the Malagasy species A. adenophorus is sister to a clade $(62 \%)$ containing the Malagasy species $A$. excelsus and the New Caledonian species A. austrocaledonicus. Within the African lineage $(100 \%)$, a clade $(100 \%)$ containing the West African rainforest species A. plagiopterus, A. staudtii, and A. macrocalyx is sister to a clade comprising the rest of the African species. Acridocarpus smeathmannii is a forest-edge (to savanna) species that is widespread across western and central Africa and is placed as sister (93\%) to the rest of Acridocarpus. The remaining clade $(99 \%)$ contains two subclades $(96 \%$ and $100 \%$, respectively); the first contains taxa restricted primarily to the coastal (and riverine) regions of West Africa (A. longifolius) and to the more arid regions of westernmost Africa (A. alternifolius and $A$. chevalieri), whereas the second contains taxa restricted to East Africa (A. ballyi, A. zanzibaricus), southern Africa (A. natalitius), and Arabia (A. orientalis). 


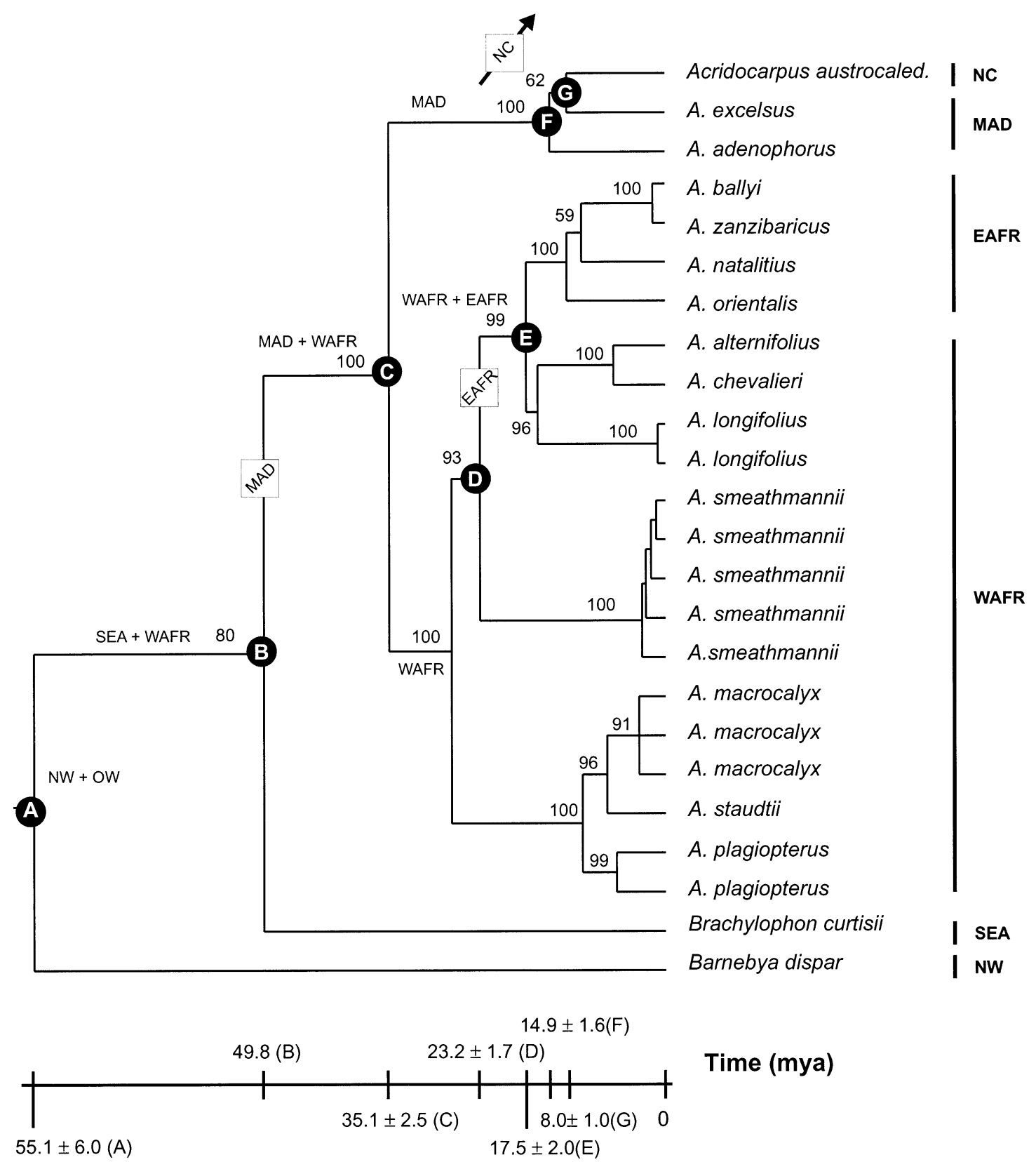

FIG. 2. Maximum-likelihood tree topology $(-\ln L=7945.63)$ estimated from combined ITS, $n d h F$, and $t r n L-F$ data showing ratesmoothed branch lengths. Bootstrap support values $\geq 50 \%$ are shown on branches. The nodes labeled A-G correspond to ancestral areas estimated from dispersal-vicariance analysis reconstructions, which are shown next to the relevant nodes. The age estimate for the basal New World-Old World disjunction at node A was previously estimated by Davis et al. (2002a). Divergence times were calculated on this tree by calibrating the ancestral node (B) of the acridocarpoids at 49.8 million years ago. This age estimate was derived from the global analysis of Malphigiaceae from $P H Y C$ and $n d h F$ data in this study. Age estimates for disjunctions labeled A-G are indicated on the scale bar below. Boxed areas indicate inferred dispersal events from ancestral area (indicated at stem node) into the area specified along the branch in the box. Modern distributions of species are indicated to the right. EAFR, East Africa (includes Arabia, and southern coastal Africa); MAD, Madagascar; NC, New Caledonia; NW, New World; OW, Old World; SEA, Southeast Asia; WAFR, West Africa (includes western and central Africa).

\section{Biogeography and Age Estimates}

The split between the Old World acridocarpoid clade from its New World ancestors (Fig. 2; node A) was inferred by Davis et al. (2002a) to be $55.1 \pm 6.0$ million years ago (mya). The estimated divergence time between Acridocarpus and Brachylophon is $49.8 \pm 5.0$ mya (Fig. 2; node B). This es- timate was used to calibrate the ancestral node of the threegene acridocarpoid tree (Fig 2; node B) and provides a minimum age estimate for that clade. Including the estimated variance around this calibration point did not greatly affect our divergence-time estimates within the acridocarpoid clade, and does not change our interpretation of these data. 
DIVA resulted in two equally optimal area reconstructions requiring three dispersals (Fig. 2), which differed only at a single node. In one reconstruction, Southeast Asia + Madagascar were assigned to node B; in the other, Southeast Asia + West Africa were assigned. We favor the latter reconstruction because these two areas consist of lowland humid forests that were much more widespread, perhaps even connected, throughout much of Africa, Europe, and Asia during the Tertiary (Wolfe 1975). The vicariance event between African and Asian taxa is estimated to be $49.8 \pm 5.0$ mya (Fig. 2; node B). Between $49.8 \pm 5.0$ (Fig. 2; node B) and $35.1 \pm$ 2.5 (Fig. 2; node C) mya, a dispersal event from West Africa to Madagascar is inferred, and the Malagasy species were completely isolated from those of the mainland by $35.1 \pm$ 2.5 mya. West African acridocarpoids began diversifying by about 26.5 mya, and between $23.2 \pm 1.7$ (Fig. 2; node D) and $17.5 \pm 2.0$ mya (Fig. 2; node E), a dispersal event is inferred from West Africa to East Africa. Finally, a dispersal event is inferred from Madagascar into New Caledonia between $14.9 \pm 1.6$ (Fig. 2; node F) and $8.0 \pm 1.0$ (Fig. 2; node G) mya.

\section{DisCUSSION}

\section{Origin and Initial Spread of Acridocarpoids}

The existence of a tropical-like, or "boreotropical", (Wolfe 1975) floristic connection across the North Atlantic during the Eocene has been viewed as critical to understanding Northern Hemisphere plant disjunctions among the mesophytic Tertiary forest refugia of eastern North America, eastern Asia, and Europe (Tiffney 1985a,b; Wen 1999; Donoghue et al. 2001; Tiffney and Manchester 2001). Similarly, Eocene connections across the North Atlantic have recently been established for animals as well (Sanmartín et al. 2001). Mounting evidence suggests that this corridor may have been far more important than previously realized, and facilitated not only the global distribution of temperate lineages, but also that of tropical groups (Lavin and Luckow 1993; Doyle and Le Thomas 1997; Fritsch 1999, 2001; Lavin et al. 2000; Chanderbali et al. 2001; Renner et al. 2001; Davis et al. 2002a). This North Atlantic corridor apparently facilitated the migration of several different lineages of Malpighiaceae from the New World to the Old World throughout the Tertiary (Davis et al. 2002a). The stem lineage that contains the acridocarpoids appears to have migrated into the Old World via Laurasia by approximately 55 mya (Figs. 2, 3; node A; Davis et al. 2002a) and coincides with the dominance of the boreotropical flora across the Northern Hemisphere during the Eocene thermal maximum.

A central question bearing on the high-latitude Tertiary migrations of plants relates not only to the timing of disjunctions between New and Old World sister clades, but also to the disjunctions of clades distributed exclusively across the Old World tropics of Asia, Africa, and Madagascar. No studies of putative boreotropical disjuncts have yet attempted to address finer scale relationships within the Old World, and the acridocarpoids bear directly on that problem. The acridocarpoids began to diversify during the Eocene with a split between African and Asian lineages approximately 50 mya (Figs. 2, 3; node B). This generally coincides with intermit- tent periods of cooling during the Eocene across northern latitudes (Berggren and Prothero 1992; Tiffney and Manchester 2001), and may correspond to a time when ancestral acridocarpoids followed equable climates southward (Davis et al. 2002a). Under this scenario, Brachylophon, which now inhabits wet forests of the Malay Peninsula, represents a relict lineage that spread into Southeast Asia during the Eocene. This is consistent with the hypothesis of the Indomalayan region as a refugium for the boreotropical flora (Wolfe 1975; Tiffney 1985b). Lowland tropical forests in this region have experienced climatological and ecological stability since the late Cretaceous, relative to their American and African counterparts (Ricklefs and Latham 1993). Moreover, land connections inferred between Southeast Asia and more northerly regions of the Northern Hemisphere could have provided migration routes between these areas throughout much of the Tertiary (Hall 1996, 1998).

Our data suggest that ancestors of Acridocarpus migrated into Africa at this time. Between about 75 and 30 mya, much of Africa was occupied by lowland rainforest very similar to that of present-day West Africa (Axelrod and Raven 1978, Figs. 6A and 6B). This includes areas of northern and central Africa, now uplifted and xeric, that would have been adjacent to Europe and most likely available for colonization from the north (Axelrod and Raven 1978, Figs. 6A and 6B). This migration route may have been greatly facilitated by land connections with North Africa via the Iberian Peninsula (Smith et al. 1994; Morley 2000) or by land filters bridging the two continents during the Tertiary (McKenna 1973; Van Couvering and Van Couvering 1976). The southerly retreat of tropical plant groups into Africa from Eurasia, such as is suggested here for Acridocarpus, represents a migrational pathway that appears to have been prominent for at least some groups during this time (Thulin 1994; Lavin et al. 2000), and macrofossils from Hungary and Slovenia (Hably and Manchester 2000), combined with phylogenetic evidence (Davis et al. 2002a), suggests the availability of this path for Malpighiaceae as well.

The estimated time of divergence between Acridocarpus and Brachylophon is supported by the absence of acridocarpoids from India. The initial impact of India with the southern margin of Eurasia is somewhat controversial, but age estimates for this event range from 58 to 42 mya (Patriat and Achache 1984; Besse and Courtillot 1988; Lee and Lawver 1995; Hall 1996, 1998; McLoughlin 2001). At least some of these estimates suggest that during the inferred southerly migration of the acridocarpoids and split between Acridocarpus and Brachylophon (about 50 mya), India was not yet available for direct land colonization by Malpighiaceae. The absence of acridocarpoids from India is especially compelling when one considers that more recently derived lineages of Malpighiaceae (e.g., the madagasikarioid clade; Davis 2002) have distributions very similar to that of the acridocarpoids, but also are found in India. We cannot eliminate the possibility, however, that members of the acridocarpoid clade were once present in India and went extinct there more recently.

Following their southward migration into Africa, populations of Acridocarpus dispersed into Madagascar from ancestors occupying lowland tropical forest between approximately 50 and 35 mya (Figs. 2, 3; nodes B and C, respec- 


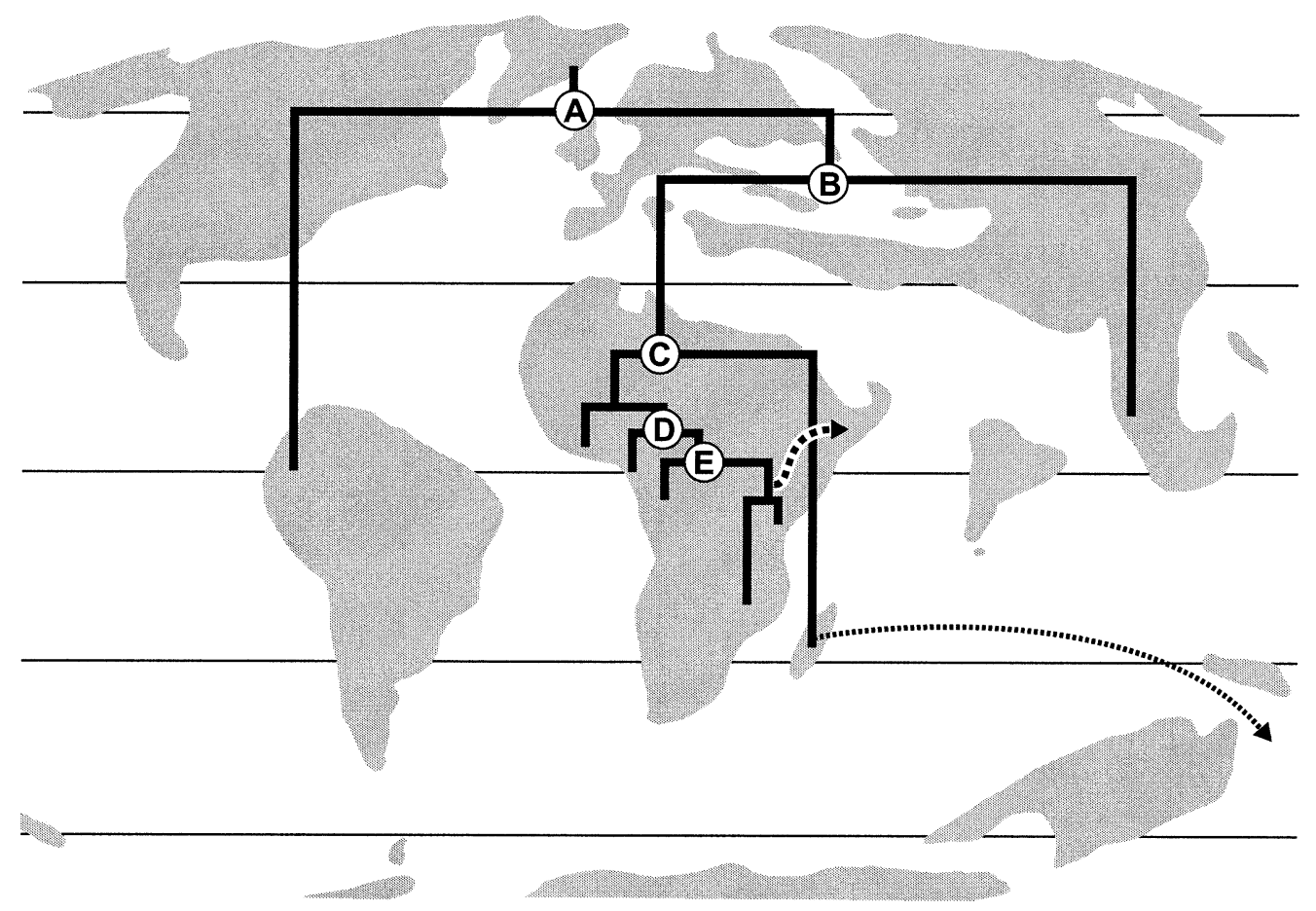

FIG. 3. Hypothesis of biogeographic history inferred for the acridocarpoids. Eocene paleogeographic map modified from Doyle and LeThomas (1997). The nodes labeled A-E correspond to dispersal-vicariance analysis reconstructions in Figure 2. The split at node A is consistent with the hypothesis of migration from the New World into Eurasia via North Atlantic land connections as postulated by Davis et al. (2002a). The split at node B represents the southern retreat of high-latitude ancestral acridocarpoids into areas of Asia (Brachylophon) and Africa (with later excursions into Madagascar; i.e., Acridocarpus). African species of Acridocarpus inhabiting lowland tropical rainforest dispersed into Madagascar along the branch leading to node $\mathrm{C}$, when forests between these landmasses were in close proximity to one another. These connections were severed during the Oligocene and coincide with the onset of dramatic restrictions of lowland humid forest in Africa as a result of Neogene aridification across the continent. Dispersal of ancestral populations of Acridocarpus species from western Africa into regions of eastern Africa between nodes D and E coincide with Miocene uplift and the formation of the East African Rift Valley, when savannas became well-established in eastern Africa. The dashed line shows movement into Arabia. The dotted line indicates long-distance dispersal from Madagascar into New Caledonia.

tively). During this period, especially in the late Eocene, lowland rainforest dominated Africa and reached its southernmost latitude (see Axelrod and Raven 1978, Fig. 6B), extending almost continuously from Africa to Madagascar. Our data suggest that connections between Africa and Madagascar were severed for acridocarpoid migrations by approximately 35 mya (Figs. 2, 3; node C). This period coincides with the initial formation of the East African Rift Valley (King 1962; Axelrod 1972a; Baker et al. 1972) and marks the onset of aridification across Africa (Axelrod 1972a; Raven and Axelrod 1974; Axelrod and Raven 1978; Smith et al. 1994).

\section{New Caledonia}

In light of the apparent absence of Acridocarpus from Asia, the phylogenetic placement of $A$. austrocaledonicus remains a perplexing biogeographic question. Acridocarpus austrocaledonicus is found in New Caledonia and represents the only discordant element in the Malpighiaceae there. All other taxa of the family in the flora of New Caledonia have close relatives in nearby Australasia (Arènes 1957). This species is well nested within the Malagasy clade (Fig. 2) and is weakly placed (62\% bootstrap) as sister to A. excelsus, which inhabits dry forests within Madagascar. In addition to support for this relationship based on our molecular data (Fig. 2), these two species and their closely related Malagasy segregate species share one striking, presumably derived, morphological similarity found in no other species in the genus (C. C. Davis, unpubl. data): a conspicuous metallic-sericeous abaxial leaf surface (versus glabrous; Sprague 1906). The latter condition (i.e., glabrous leaves) is found in other Malagasy species that represent the basal lineages within the Malagasy clade, and is presumably the ancestral condition within that clade (C. C. Davis, unpubl. data). The close relationship between A. excelsus and A. austrocaledonicus was postulated by both Sprague (1906) and Niedenzu (1928), and represents one of the few monophyletic groups Niedenzu (1928) recognized in his treatment of the genus (C. C. Davis, unpubl. data).

The dispersal from Madagascar to New Caledonia, approximately 15-8 mya (Fig. 2; nodes F and G, respectively), occurred well after any known land route was available between these areas, and appears to represent one instance of long-distance dispersal. This dispersal may have been facilitated by the onset of dramatic monsoon activity that began approximately 8 mya (Krause et al. 1997). The New Caledonian flora is thought to comprise members of relictual lineages representing the earliest-diverging angiosperms and 
more recently derived clades from adjacent areas of Australasia (Lowry 1998). Acridocarpus austrocaledonicus is not a relictual lineage of early-diverging flowering plants and does not have sister taxa represented in Australasia. Instead, the phylogenetic placement and distribution of A. austrocaledonicus suggests that at least some members of this flora are not recent immigrants from Australasia, but are from areas not immediately adjacent to New Caledonia (e.g., Madagascar). It is possible that populations of Acridocarpus dispersed from Madagascar into adjacent Australasia, subsequently migrated into New Caledonia, and then went extinct in Australasia. Evidence of direct dispersal from Madagascar to Australia is available for at least some groups (Raven and Axelrod 1974; Baum et al. 1998; Long et al. 1998), but auxiliary data are needed to confirm this scenario for Acridocarpus.

\section{African Biogeography}

African aridification greatly accelerated in the early Miocene, largely as a result of the uplift of the continent and the further development of the East African Rift Valley (King 1962; Axelrod 1972a; Baker et al. 1972). During this period, widespread lowland tropical forest was replaced in many areas by savannas (Retallack et al. 1990). Fossil evidence from sites throughout East Africa indicates that savannas were prominent in these areas by around 23-17 mya (Axelrod and Raven 1978; Olson and Rasmussen 1986; Retallack 1990; Retallack et al. 1990). Many humid tropical plant lineages were most likely extirpated from Africa at this time (Axelrod 1972a; Raven and Axelrod 1974; Axelrod and Raven 1978).

Members of Acridocarpus, however, apparently survived this period of dramatic ecological change, presumably in the dwindling rainforest, which today is restricted to parts of West Africa. Our phylogenetic evidence suggests that these rainforest relicts continued to diversify in western humid forests between approximately 27 and 23 mya and that a dispersal from western Africa to eastern Africa occurred between approximately 23 and 17 mya (Figs. 2, 3; node D and $\mathrm{E}$, respectively). Thus, this invasion coincides almost exactly with the first formations of East African savannas.

The phylogeny and distribution of West African Acridocarpus species suggest that lineages diversified in response to widespread aridification. The earliest diverging representatives among the African group (A. macrocalyx, A. plagiopterus, and $A$. staudtii) are typically distributed in the wettest parts of lowland rainforest in West Africa. They are sister to a larger clade of increasingly drought tolerant species. For example, A. smeathmannii usually inhabits drier parts of the forest margin in these lowland humid tropical regions. Similarly, A. longifolius is restricted primarily to functionally xeric sandy coastal (or riverine) areas, and A. alternifolius and $A$. chevalieri are mostly restricted to much drier regions of westernmost Africa in transitional zones between rainforest and savanna vegetation. The latter three species appear to be tolerant of subxeric to xeric climates, and form a wellsupported clade with species distributed in the driest parts of eastern Africa (A. ballyi, A. zanzibaricus, A. natalitius, and A. orientalis). A similar phylogenetic pattern would result from the extinction of drought-tolerant members from the basal mesic West African clades. However, there is no evidence to suggest that such taxa existed, and this pattern of phylogenetically nested sets of increasingly drought-tolerant species is fully consistent with the general model of African climatic history of progressively dryer conditions in the Miocene. Acridocarpus, instead of becoming extinct like many other taxa originally adapted to humid tropical conditions, has apparently adapted to arid areas of Africa while maintaining a presence in its ancestral humid evergreen African lowland forests.

The pattern of migration from lowland tropical Africa to Madagascar and subsequently to xeric regions of eastern and southern Africa reported here may be common in tropical African groups with representatives in both humid and xeric forests (see also Axelrod 1972a). If so, the diversification of paleoendemics in response to climatological change could partly explain the tremendous diversity and endemism of Madagascar and of regions of eastern and southern Africa. This appears to have occurred in African legume groups thought to have originated from Laurasia that diversified with the establishment of savanna vegetation (Thulin 1994; Lavin et al. 2000). This is especially true for Ormocarpum, a primarily African clade in which the basal branches are West African, and nested lineages are East African (Lavin et al. 2000; Thulin and Lavin 2001; M. Lavin, pers. comm. 2002). Additionally, the distribution of at least some disjunct groups between West Africa and Madagascar (Axelrod 1972a) may reflect their inability to adapt to intervening dry environments.

\section{ACKNOWLEDGMENTS}

The authors thank D. Abbiw, K. Abdul-Salim, J. Andriantiana, M. Cheek, J. Amponsah, P. Ekbe, and F. Mbago for providing helpful assistance in the field; administrative and logistical support was provided by the Missouri Botanical Garden, the University of Ghana at Legon, the National Herbarium of Cameroon, and the University of Dar es Salaam; L. Andriamahefarivo, P. Lowry, P. Phillipson, H. Schmidt, and M. Cheek helped to facilitate field research in Africa and Madagascar under the auspices of the Missouri Botanical Garden and the Royal Botanic Gardens, Kew; W. Anderson, D. Baum, M. Donoghue, M. Lavin, D. Middleton, P. Stevens, A. Yoder, and two anonymous reviewers added very useful comments to earlier versions of this manuscript; DNA was kindly provided by M. Chase and P. Sirirugsa. E. Wood and the staff at the Harvard University Herbaria greatly helped with the herbarium collections required for this research. Funding for this study was provided by the Department of Organismic and Evolutionary Biology at Harvard University, a Deland Grant from the Arnold Arboretum, and National Science Foundation Grant DEB-0073299. Administrative and intellectual support were provided to CCD by the Michigan Society of Fellows at the University of Michigan to help complete this study.

\section{Literature Cited}

Anderson, W. R., and B. Gates. 1981. Barnebya, a new genus of Malpighiaceae from Brazil. Brittonia 33:275-284.

Arènes, J. 1957. Répartition géographique des Malpighiacées vi- 
vantes et fossiles (1). C. R. Somm. Seances Soc. Biogeogr. 290: 81-108.

Axelrod, D. I. 1972a. Ocean-floor spreading in relation to ecosystematic problems. Univ. Ark. Mus. Occas. Pap. 4:15-68.

1972b. Edaphic aridity as a factor in Angiosperm evolution. Am. Nat. 106:311-320.

Axelrod, D. I., and P. H. Raven. 1978. Late Cretaceous and Tertiary vegetation history of Africa. Pp. 77-130 in M. J. A. Werger, ed. Biogeography and ecology of southern Africa. Dr W. Junk bv Publishers, The Hague, The Netherlands.

Baker, B. H., P. A. Mohr, and L. A. J. Williams. 1972. Geology of the eastern rift system of Africa. Geol. Soc. Am. Spec. Pap. 136:1-67.

Baldwin, B. G., and M. J. Sanderson. 1998. Age and rate diversification of the Hawaiian silversword alliance (Compositae). Proc. Natl. Acad. Sci. USA 95:9402-9406.

Baum, D. A., R. L. Small, and J. F. Wendel. 1998. Biogeography and floral evolution of Baobabs (Adansonia, Bombacaceae) as inferred from multiple data sets. Syst. Biol. 47:181-207.

Bartek, L. R., L. C. Sloan, J. B. Anderson, and M. I. Ross. 1992. Evidence from the Antarctic continental margin of late Paleogene ice sheets: a manifestation of plate reorganization and synchronous changes in atmospheric circulation over the emerging southern ocean? Pp. 131-159 in D. R. Prothero and W. A. Berggren, eds. Eocene-Oligocene climatic and biotic evolution. Princeton Univ. Press, Princeton, NJ.

Berggren, W. A., and D. R. Prothero. 1992. Eocene-Oligocene climatic and biotic evolution: an overview. Pp. 1-28 in D. R. Prothero and W. A. Berggren, eds. Eocene-Oligocene climatic and biotic evolution. Princeton Univ. Press, Princeton, NJ.

Besse, J., and V. Courtillot. 1988. Paleographic maps of the continents bordering the Indian Ocean since the Early Jurassic. J. Geophys. Res. 93:11791-11808.

Cameron, K. M., M. W. Chase, W. R. Anderson, and H. G. Hills. 2001. Molecular systematics of Malpighiaceae: evidence from plastid $r b c L$ and matK sequences. Am. J. Bot. 88:1847-1862.

Campbell, C. S., M. F. Wojciechowski, B. G. Baldwin, L. A. Alice, and M. J. Donoghue. 1997. Persistent nuclear ribosomal DNA sequence polymorphism in the Amelanchier agamic complex (Rosaceae). Mol. Biol. Evol. 14:81-90.

Chanderbali, A. S., H. van der Werff, and S. S. Renner. 2001. Phylogeny and historical biogeography of Lauraceae: evidence from the chloroplast and nuclear genomes. Ann. Mo. Bot. Gard. 88:104-134.

Davis, C. C. 2002. Madagasikaria (Malpighiaceae): a new genus from Madagascar with implications for floral evolution in Malpighiaceae. Am. J. Bot. 89:723-730.

Davis, C. C., W. R. Anderson, and M. J. Donoghue. 2001. Phylogeny of Malpighiaceae: evidence from chloroplast $n d h F$ and trnL-F nucleotide sequences. Am. J. Bot. 88:1830-1846.

Davis, C. C., C. D. Bell, S. Mathews, and M. J. Donoghue. 2002a. Laurasian migration explains Gondwanan disjunctions: evidence from Malpighiaceae. Proc. Natl. Acad. Sci. USA 99:6833-6837.

Davis, C. C., P. W. Fritsch, J. Li, and M. J. Donoghue. 2002 b. Phylogeny and biogeography of Cercis (Fabaceae): evidence from nuclear ribosomal ITS and chloroplast $n d h F$ sequence data. Syst. Bot. 27:289-302.

Donoghue, M. J., C. D. Bell, and J. Li. 2001. Phylogenetic patterns in northern hemisphere plant geography. Int. J. Plant Sci. 162: S41-S52.

Doyle, J. A. and A. Le Thomas. 1997. Phylogeny and geographic history of Annonacaeae. Geogr. Phys. Quat. 51:353-361.

Farris, J. S., M. Källersjö, A. G. Kluge, and C. Bult. 1994. Testing significance of incongruence. Cladistics 10:315-319.

Felsenstein, J. 1981. Evolutionary trees from DNA sequences: a maximum likelihood approach. J. Mol. Evol. 17:368-376.

125:1 1985. Phylogenies and the comparative method. Am. Nat. 125:1-15.

Fritsch, P. W. 1999. Phylogeny of Styrax based on morphological characters, with implications for biogeography and infrageneric classification. Syst. Bot. 24:356-378.

_ 2001. Phylogeny and biogeography of the flowering plant genus Styrax (Styracaceae) based on chloroplast DNA restriction sites and DNA sequences of the internal transcribed spacer region. Mol. Phylogenet. Evol. 19:387-408.

Germeraad, J. H., C. A. Hopping, and J. Muller. 1968. Palynology of Tertiary sediments from tropical areas. Rev. Palaeobot. Palynol. 6:189-348.

Grove, A. T. 1978. Africa. 3rd ed. Oxford Univ. Press, London.

Hably, L., and S. R. Manchester. 2000. Fruits of Tetrapterys (Malpighiaceae) from the Oligocene of Hungary and Slovenia. Rev. Paleobot. Palynol. 111:93-101.

Hall, R. 1996. Reconstructing Cenozoic Southeast Asia. Geol. Soc. Spec. Pub. 106:153-184.

1998. The plate tectonics of Cenozoic Southeast Asia and the distribution of land and sea. Pp. 99-131 in R. Hall and J. D. Holloway, eds. Biogeography and geological evolution of Southeast Asia. Backhuys Publishers, Leiden, The Netherlands.

Holmgren, P. K., N. H. Holmgren, and L. C. Barnett. 1990. Index Herbariorum. New York Botanical Garden, Bronx, NY.

King, L. C. 1962. The geomorphology of the Earth: a study and synthesis of world scenery. Hafner, New York.

Krause, D. W., J. H. Hartman, and N. A. Wells. 1997. Late Cretaceous vertebrates from Madagascar. Pp. 3-43 in S. M. Goodman and B. D. Patterson, eds. Natural change and human impact in Madagascar. Smithsonian Institution Press, Washington, DC.

Larson, A. 1994. The comparison of morphological and molecular data in phylogenetic systematics. Pp. 371-390 in B. Schierwater, B. Streit, G. P. Wagner, and R. DeSalle, eds. Molecular ecology and evolution: approaches and applications. Birkhauser Verlag, Basel, Switzerland.

Lavin, M., and M. Luckow. 1993. Origins and relationships of tropical North America in the context of the boreotropics hypothesis. Am. J. Bot. 80:1-14.

Lavin, M., M. Thulin, J.-N. Labat, and R. T. Pennington. 2000. Africa, the odd man out: molecular biogeography of Dalbergioid Legumes (Fabaceae) suggests otherwise. Syst. Bot. 25:449-467.

Lee, T.-Y., and L. A. Lawver. 1995. Cenozoic plate reconstruction of Southeast Asia. Tectonophysics 251:85-138.

Long, J. A., R. Vickers-Rich, K. Hirsch, E. Bray, and C. Tuniz. 1998. The Cervantes egg: an early Malagasy tourist to Australia. Rec. West. Aust. Mus. 19:39-46.

Lowry, P. P. 1998. Diversity, endemism, and extinction in the flora of New Caledonia: a review. Acad. Sin. Monogr. Ser. 16: 181-206.

Mathews, S., and M. J. Donoghue. 1999. The root of angiosperm phylogeny inferred from duplicate phytochrome genes. Science 286:947-950.

McKenna, M. C. 1973. Sweepstakes, filters, corridors, Noah's Arks, and beached Viking funeral ships in paleogeography. Pp. 295308 in D. H. Tarling and S. K. Rungcorn, eds. Implications of continental drift to the earth sciences. Vol. 1. Academic Press, London.

McLoughlin, S. 2001. The breakup history of Gondwana and its impact on pre-Cenozoic floristic provincialism. Aust. J. Bot. 49: 271-300.

Morley, R. J. 2000. Origin and evolution of tropical rain forests. John Wiley and Sons, New York.

Niedenzu, F. 1928. Malpighiaceae. Pp. 1-870 in A. Engler, ed. Das Pflanzenreich IV, 141. Wilhelm Engelmann, Leipzig, Germany.

Olmstead, R. G., and J. A. Sweere. 1994. Combining data in phylogenetic systematics: an empirical approach using three molecular data sets in the Solanaceae. Syst. Biol. 43:467-481.

Olson, S. L., and D. Rasmussen. 1986. Paleoenvironment of the earliest hominids: new evidence from the Oligocene avifauna of Egypt. Science 233:1202-1204.

Patriat, P., and J. Achache. 1984. India-Eurasia collision chronology has implications for crustal shortening and driving mechanisms of plates. Nature 311:615-621.

Potts, R., and A. K. Behrensmeyer. 1992. Late Cenozoic terrestrial ecosystems. Pp. 419-541 in A. K. Behrensmeyer, J. D. Damuth, W. A. DiMichele, R. Potts, H.-D. Sues, and S. L. Wing, eds. Terrestrial ecosystems through time: evolutionary paleoecology of terrestrial plants and animals. Univ. of Chicago Press, Chicago, IL.

Rambaut, A., and N. C. Grassly. 1997. Seq-Gen: an application for 
the Monte Carlo simulation of DNA sequence evolution along phylogenetic trees. Comput. Appl. Biosci. 13:235-238.

Raven, P. H., and D. I. Axelrod. 1974. Angiosperm biogeography and past continental movements. Ann. Mo. Bot. Gard. 61: 39-637.

Renner, S. S., G. Clausing, and K. Meyer. 2001. Historical biogeography of Melastomataceae: the roles of Tertiary migration and long-distance dispersal. Am. J. Bot. 88:1290-1300.

Retallack, G. P. 1990. Soils of the past. Unwin-Hyman, London.

Retallack, G. J., D. P. Dugas, and E. A. Bestland. 1990. Fossil soils and grasses of a Middle Miocene East African grassland. Science 247:1325-1328.

Ricklefs, R. E., and R. E. Latham. 1993. Global patterns of diversity in mangrove floras. Pp. 215-229 in R. E. Ricklefs and D. Schluter, eds. Species diversity in ecological communities. Univ. of Chicago Press, Chicago, IL.

Ronquist, F. 1996. DIVA. Ver. 1.1. Computer program and manual available from the author via ftp.uu.se or ftp.systbot.uu.se. Dept. of Evolutionary Biology, Uppsala University, Uppsala, Sweden.

. 1997. Dispersal-vicariance analysis: a new approach to the quantification of historical biogeography. Syst. Biol. 46: 195-203.

Sanderson, M. J. 1997. A nonparametric approach to estimating divegence times in the absence of rate constancy. Mol. Biol. Evol. 14:1218-1231.

Sanmartín, I., H. Enghoff, and F. Ronquist. 2001. Patterns of animal dispersal, vicariance and diversification in the Holarctic. Biol. J. Linn. Soc. 73:345-390.

Smith, A. G., D. G. Smith, and B. M. Funnell. 1994. Atlas of Mesozoic and Cenozoic coastlines. Cambridge Univ. Press, Cambridge, UK.

Sprague, T. A. 1906. A revision of Acridocarpus. J. Bot. 19: 192-207.

Stebbins, G. L. 1952. Aridity as a stimulus to plant evolution. Am. Nat. 86:33-44.

Swofford, D. L. 2000. PAUP*: phylogenetic analysis using parsimony (*and other methods). Ver. 4. Sinauer, Sunderland, MA.

Taylor, D. W., and W. Crepet. 1987. Fossil floral evidence of Malpighiaceae and an early plant-pollinator relationship. Am. J. Bot. $74: 274-286$.
Templeton, A. R. 1983. Phylogenetic inference from restriction endonuclease cleavage site maps with particular reference to the evolution of humans and the apes. Evolution 37:221-244.

Thulin, M. 1994. Aspects of disjunct distributions and endemism in the arid parts of the Horn of Africa, particularly Somalia. Pp. 1105-1119 in J. H. Seyani and A. C. Chikuni, eds. Proceedings of the 13th plenary meeting AETFAT. Vol. 2. National Herbarium and Botanic Gardens, Zomba, Malawi.

Thulin, M., and M. Lavin. 2001. Phylogeny and biogeography of the Ormocarpum group (Fabaceae): a new genus Zygocarpum from the horn of Africa region. Syst. Bot. 26:299-317.

Tiffney, B. H. 1985a. Perspectives on the origin of the floristic similarity between eastern Asia and eastern North America. J. Arnold Arbor. Harv. Univ. 66:73-94.

. 1985b. The Eocene North Atlantic land bridge: its importance in Tertiary and modern phytogeography of the Northern Hemisphere. J. Arnold Arbor. Harv. Univ. 66:243-273.

Tiffney, B. H., and S. R. Manchester. 2001. The use of geological and paleontological evidence in evaluating plant phylogenetic hypotheses in the Northern Hemisphere Tertiary. Int. J. Plant Sci. 162:S3-S17.

Van Couvering, J. A., and J. A. H. Van Couvering. 1976. Early Miocene mammal fossils from East Africa: aspects of geology, faunistics and paleo-ecology. Pp. 155-198 in G. L. Isaac and E. R. McCown, eds. Human origins: Louis Leaky and the East African evidence. W. A. Benjamin, Menlo Park, CA.

Wen, J. 1999. Evolution of eastern Asian and eastern North American disjunct distributions in flowering plants. Annu. Rev. Ecol. Syst. 30:421-455.

Wendel, J. F., A. Schnabel, and T. Seelanan. 1995. Bidirectional interlocus concerted evolution following allopolyploid speciation in cotton. Proc. Natl. Acad. Sci. USA 92:280-284.

White, F. 1983. The vegetation of Africa. UNESCO Publishing, Paris.

Whitmore, T. C. 1998. An introduction to tropical rain forests. $2 \mathrm{~d}$ ed. Oxford Univ. Press, Oxford, UK.

Wolfe, J. A. 1975. Some aspects of plant geography of the Northern Hemisphere during the late Cretaceous and Tertiary. Ann. Mo. Bot. Gard. 62:264-279.

Corresponding Editor: A. Yoder 